\title{
Phénomènes de coopération et d'inhibition entre les bactéries lactiques utilisées en industrie laitière
}

\author{
V. JUILLARD, H.E. SPINNLER, M.J. DESMAZEAUD, C.Y. BOQUIEN \\ I.N.R.A., Laboratoire de Microbiologie laitière, 78350 Jouy-en-Josas, France
}

\section{Résumé}

La propagation empirique des levains lactiques a conduit à l'utilisation d'associations complexes de bactéries lactiques. Aujourd'hui, la possibilité de produire des souches pures permettrait de les associer de façon raisonnée suivant des critères technologiques (vitesse d'acidification, qualité aromatique), ou mieux, de les produire en mélange en contrôlant leur qualité. Dans ces deux cas, la connaissance des interactions entre ces souches serait très appréciable. Malheureusement, l'appréhension de ces interactions ne dépasse que rarement la connaissance qualitative de leurs effets. Cette revue rend compte des données concernant l'étude des interactions entre différentes souches souvent associées.

Les interactions positives entre les souches sont regroupées sous le terme de coopération. Celle-ci peut s'exprimer en stimulant la croissance des souches ou la production de métabolites particuliers (acides lactiques, arômes). Celle-ci peut avoir pour origine la modification des substrats (en particulier des sources azotées) ou des conditions de milieu ( $\mathrm{pH}$, élimination d'inhibiteurs).

Les interactions négatives ou inhibitions peuvent avoir pour origine la production de composés toxiques (bactériocines, antibiotiques ou autres métabolites), la compétition vis-à-vis du substrat ou le rejet de catabolites.

La quantification de ces données en terme de cinétique ou de rendement fait défaut. Ceci est en partie dû à la lourdeur des méthodologies dont on dispose actuellement pour mesurer ces interactions. La mise en place de nouvelles méthodes devrait permettre de mieux connaître ces phénomènes et à terme de pouvoir mieux gérer la production et l'utilisation de ces levains.

Mots clés : Bactéries lactiques - Coopération - Inhibition - Acidification - Catabolisme Dynamique des populations.

\section{Summary}

Cooperation and inhibition between lactic acid bacteria used in dairy industry

The rule of thumb propagation of lactic starters brought about the utilization of complex associations of lactic acid bacteria. Today, the ability to produce pure strains should permit to associate them following technological criteria (speed of acidification, 
aromas...) or better than that to grow them together following the quality of the mixture. In both case the knowledge of interactions between the strains would be positive. Unfortunately, the knowledge of these interactions overstep seldom the qualitative knowledge of their effects. This review takes into account the datas about interactions between different strains, usually used together.

The positive interactions between strains are called cooperation. The expression of this one can be observed by a better growth or better production of metabolites (lactic acids, aroma...). Its origin can be the modification of substrates (e.g. nitrogen sources) or medium parameters ( $\mathrm{pH}$, elimination of inhibitors).

The reason of negative interactions called inhibitions can be found in toxic metabolites production (bacteriocines, antibiotics or other metabolites), competition for substrate consumption, or catabolites accumulation.

In many cases these data are only qualitative. Their quantifications (kinetics or yield) would be useful. However, at the moment, the methods used for these estimations are very heavy. New methods of measurement would permit to obtain a better knowledge of these phenomena and to manage better the starter production and utilization.

Key words : Lactic acid bacteria - Cooperation - Inhibition - Acidification - Catabolism - Population dynamics.

\section{Introduction}

Le rôle des levains lactiques est double : d'une part, ils sont responsables de l'acidification du lait, du fait de la production d'acide lactique ; d'autre part, leur métabolisme est à l'origine des modifications de texture et de flaveur permettant d'aboutir à la qualité organoleptique du produit final (CoGAN, 1980). Considérons l'exemple du yoghourt (Accolas et al., 1980) : la faible valeur du $\mathrm{pH}$ final empêche le développement de germes indésirables (producteurs de gaz, putréfiants), et évite le développement de germes pathogènes. De plus, le métabolisme des souches est, en grande partie, responsable de la qualité organoleptique du produit final. Dans le cas des fromages à pâte cuite (Accolas et al., 1980), la protéolyse joue un rôle fondamental : en modifiant les propriétés rhéologiques, et en provoquant l'apparition de composés d'arôme (ou de précurseurs); l'acidification permet, quant à elle, d'éliminer l'eau du caillé dans de bonnes conditions (phénomène de synérèse). L'étude des propriétés organoleptiques du beurre et des fromages à pâte molle a permis de mettre en évidence la dualité des levains mésophiles (COGAN, 1980). En effet, les cultures qui déterminaient un bon développement d'arôme contenaient en fait un mélange de deux types de bactéries lactiques, l'un produisant une plus grande quantité d'acide lactique et l'autre produisant des quantités d'arômes plus élevés.

Pour la fabrication de nouveaux types de pâtes ayant un $\mathrm{pH}$ et un degré de minéralisation élevé au démoulage (pâtes solubilisées), des associations de Streptococcus thermophilus et de souches mésophiles sont utilisées (PERNODET, 1984). On ne dispose actuellement d'aucune information pour les interactions entre ces souches. 
On peut classer les levains utilisés en deux grandes familles (STADHOUdERS et LEENDERS, 1984) :

- Les levains mixtes (mixed strain starters des anglo-saxons). Ils sont formés d'un mélange de souches en nombre et en proportions indéfinis contenant des souches acidifiantes et des souches aromatisantes. Ces souches appartiennent à différents types lysotypiques et ont donc, en général, une bonne activité acidifiante. Cependant, STADHouders et Leenders (1984) soulignent que, si un mélange de ce type n'est pas attaqué régulièrement par des phages variés, une souche peut devenir dominante et ce mélange peut être très sensible aux phages (ceux susceptibles d'attaquer la souche dominante). De plus, la régularité de la qualité des fromages obtenus par cette méthode est difficile à maîtriser.

- Les cultures pures (single strain starters des anglo-saxons) sont des souches sélectionnées en vue d'obtenir une régularité des propriétés organoleptiques et d'acidification. Cela exige une sélection rigoureuse, en particulier en ce qui concerne la résistance aux attaques des bactériophages. Ces souches peuvent ensuite être mélangées dans les proportions voulues suivant l'utilisation que l'on désire en faire.

LAWRENCE et al. (1984) montrent comment en Nouvelle-Zélande, en quelques années, certains producteurs de Cheddar sont passés d'un travail avec 3 couples de bactéries ayant des lysotypes différents à un seul couple de bactéries du fait de leurs exceptionnelles résistances aux phages.

Le type de produit à fabriquer détermine les levains à employer. Ainsi, pour les pâtes molles, les levains utilisés sont des bactéries mésophiles. On peut utiliser des mélanges de souches pures de Streptococcus cremoris, Streptococcus lactis, Streptococcus lactis subsp. diacetylactis et Leuconostoc.

Qui dit' association de cultures dit possibilité d'interactions : si elles sont bénéfiques pour l'une des souches ou les deux, on parlera alors de coopération entre les cultures. Si elles sont néfastes pour l'une des souches ou les deux, on parlera d'inhibition. Le terme de coopération regroupe donc les notions de commensalisme (interaction ayant un effet positif sur une des deux souches), de mutualisme et de protocoopération (interactions ayant un effet positif sur les deux souches, la première notion impliquant le caractère impérieux de l'interaction pour la survie des deux organismes, à l'inverse de la seconde). Le terme d'inhibition désigne, quant à lui, les notions d'amensalisme (interaction ayant un effet négatif sur une des deux souches) et de compétition, toutes notions qui ont été définies par FredERICKSON (1977).

L'objectif de cette revue bibliographique est donc de faire le point sur l'état des connaissances en matière d'interactions entre les bactéries lactiques utilisées en industrie laitière. Nous n'avons étudié que les phénomènes d'interactions « indirectes » (FrEDERICKSON, 1977), laissant volontairement de côté le problème des bactéries lysogènes. Nous examinerons donc successivement les phénomènes de coopération et les phénomènes d'inhibition, puis nous évoquerons en conclusion, les conséquences technologiques de tels phénomènes. 


\section{Les phénomènes de coopération}

\section{A. Mise en évidence}

La coopération, qui se définit comme une interaction positive entre les souches, peut être mise en évidence de plusieurs manières (tabl. 1).

\section{Croissance des souches}

Bien que la quantification rigoureuse d'une vitesse de croissance soit complexe, il s'agit du critère le plus commun pour démontrer ce type d'interactions. Moon et Reinbold (1976), dans leur étude sur un mélange de cultures pures de $L$. bulgaricus et $S$. thermophilus ont prouvé l'existence d'une coopération en comparant les vitesses de croissance des souches, cultivées soit seules, soit en mélanges. Ces auteurs ont montré que les taux de croissance sont, eux aussi, améliorés en culture mixte. En utilisant une culture mixte où le rapport des nombres de $L$. bulgaricus/S. thermophilus est de l'ordre de 2 dans l'inoculum, le taux de croissance de $S$. thermophilus est plus du double de celui obtenu avec une culture pure de la même souche. Cette coopération se traduit, en fin de phase exponentielle de croissance, par une augmentation de $50 \%$ du nombre de $S$. thermophilus en culture mixte par rapport aux dénombrements effectués en culture pure. C'est aussi en comparant les croissances que PetTe et LolKema (1950a) avaient mis en évidence la coopération : un simple comptage des bactéries indique que le nombre de cellules de $S$. thermophilus après $3 \mathrm{~h}$ d'incubation à $45^{\circ} \mathrm{C}$ est plus élevé dans le cas d'une culture mixte avec $L$. bulgaricus que dans le cas d'une culture pure. DRIESSEN et al. (1982) ont montré qu'il était possible de maintenir une population de $L$. bulgaricus, dans une fabrication continue de yoghourts, avec des taux de dilution deux fois plus élevés en culture mixte qu'en culture pure. Ceci confirme à l'évidence la coopération entre les deux souches du point de vue des taux de croissance.

\section{Acidification}

L'étude comparée de l'acidification est certainement le critère le plus couramment employé, dans le cas des bactéries lactiques. Petre et LolKema (1950a) l'ont d'ailleurs utilisé conjointement avec la mesure de la croissance des souches, en estimant la production d'acide lactique avec de la soude décinormale (tabl. 1).

Accolas et al. (1977) ont utilisé la même méthodologie pour étudier les propriétés acidifiantes des bactéries lactiques thermophiles. L'effet stimulant d'une souche sur une autre était apprécié en comparant la quantité d'acide produite par la culture mixte à la somme des quantités produites par les cultures pures (fig. 1).

Enfin, Hemme et al. (1981) ont mis en évidence l'effet stimulant d'extraits de lactobacilles thermophiles sur la production d'acide de $S$. thermophilus, en observant une diminution plus rapide du $\mathrm{pH}$ du milieu de culture après un temps donné d'incubation, lorsqu'ils ajoutaient ces extraits. 


\section{TABLeaU I}

Récapitulatif des principales études effectuées sur les facteurs stimulant Lactobacillus bulgaricus ou Streptococcus thermophilus

Summary of the main studies realized on Lactobacillus bulgaricus or Streptococcus thermophilus stimulating factors

\begin{tabular}{|c|c|c|c|}
\hline Référence & $\begin{array}{c}\text { Facteur } \\
\text { de stimulation } \\
\text { de } L . \text { bulgaricus }\end{array}$ & $\begin{array}{cl} & \text { Facteur } \\
\text { de } & \text { stimulation } \\
\text { de } S . & \text { thermophilus }\end{array}$ & Méthode de mesures \\
\hline $\begin{array}{l}\text { GALESLOOT et al. } \\
\text { (1968) }\end{array}$ & Formiate & & $\begin{array}{l}\text { Vitesse moyenne } \\
\text { d'acidification }\end{array}$ \\
\hline $\begin{array}{l}\text { VERINGA et al. } \\
\text { (1968) }\end{array}$ & & & \\
\hline $\begin{array}{r}\text { Accolas et al. } \\
\text { (1971) }\end{array}$ & $\begin{array}{l}\text { Surnageants } \\
\text { de cultures } \\
\text { de streptocoques } \\
\text { - formiate } \\
\text { - adenine }\end{array}$ & $\begin{array}{l}\text { Surnageants } \\
\text { de cultures } \\
\text { de lactobacilles }\end{array}$ & \\
\hline $\begin{array}{l}\text { Higashio et al. } \\
\text { (1978) }\end{array}$ & $\begin{array}{l}\text { Formiate } \\
\text { et pyruvate }\end{array}$ & $\begin{array}{l}\text { Val, Glys, His, } \\
\text { Glu, Leu }\end{array}$ & \\
\hline $\begin{array}{l}\text { DRIESSEN et al. } \\
\text { (1982) }\end{array}$ & $\begin{array}{l}\text { Formiate } \\
\mathrm{CO}_{2} \mathrm{HCO}_{3-}\end{array}$ & & $\begin{array}{l}\text { Taux de croissance } \\
\text { (estimé en culture } \\
\text { continue) }\end{array}$ \\
\hline $\begin{array}{l}\text { Pette et Lolkema } \\
\text { (1950) }\end{array}$ & & $\begin{array}{l}\text { Acides aminés } \\
\text { (valine) }\end{array}$ & $\begin{array}{l}\text { Numérations } \\
\text { et activités } \\
\text { acidifiante }\end{array}$ \\
\hline $\begin{array}{l}\text { BAutista et al. } \\
\quad(1966)\end{array}$ & & $\begin{array}{l}\text { Activité } \\
\text { protéolytique }\end{array}$ & \\
\hline $\begin{array}{l}\text { Desmazeaud } \\
\text { et Hermier } \\
(1973)\end{array}$ & & Peptides exogènes & \\
\hline $\begin{array}{l}\text { MoON et REINBold } \\
\text { (1976) }\end{array}$ & & $\begin{array}{l}\text { Filtrats de cultures } \\
\text { de } L . \text { bulgaricus }\end{array}$ & \\
\hline $\begin{array}{l}\text { SHANKAR et Davies } \\
\quad(1978)\end{array}$ & & $\begin{array}{l}\text { Protéinases } \\
\text { de Lactobacillus }\end{array}$ & \\
\hline $\begin{array}{l}\text { BRACQUART et al. } \\
\text { (1978) }\end{array}$ & & $\begin{array}{l}\text { Glu, Met, Tyr., } \\
\text { Cys, Phe, His. Arg. }\end{array}$ & $\begin{array}{l}\text { Vitesse } \\
\text { d'acidification }\end{array}$ \\
\hline $\begin{array}{l}\text { BRACQUART } \\
\text { et LORIENT } \\
(1979)\end{array}$ & & $\begin{array}{l}\text { Glu-His, His-Glu, } \\
\text { Met-His-Glu, } \\
\text { Glu-His-Met }\end{array}$ & \\
\hline $\begin{array}{l}\text { RADKE-MITCHELL } \\
\text { et SANDINE } \\
(1984)\end{array}$ & & $\begin{array}{l}\text { Complémentarité } \\
\text { entre protéinases } \\
\text { de Lactobacillus } \\
\text { et aminopeptidase } \\
\text { de Streptococcus }\end{array}$ & \\
\hline
\end{tabular}




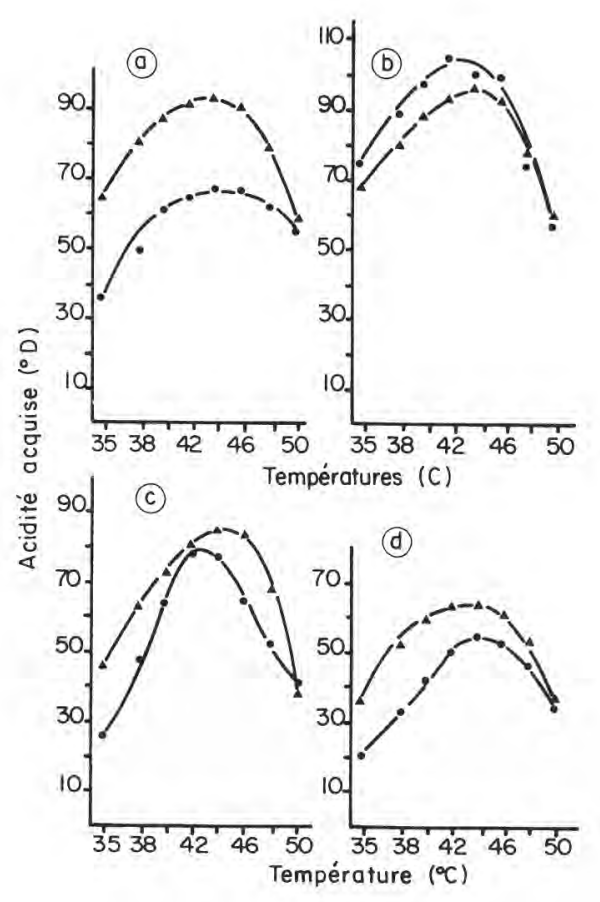

Fig. 1

Production d'acide de cultures mixtes de Streptococcus thermophilus et de Lactobacillus, et des cultures pures correspondantes (d'après Accolas et al., 1977).

Acid production by mixed cultures of $\mathrm{S}$. thermophilus and Lactobacillus, and by respective single strains (from AcCOLAS et al., 1977).

$a$ : - Somme moyenne des acidités produites par les cultures pures de L. bulgaricus 369 et de S. thermophilus 160, 302, 368.

Average sum of acid production by single strains of $\mathrm{L}$. bulgaricus 369 and $\mathrm{S}$. thermophilus 160, 302 and 368 .

A- A Acidité moyenne des acidités produites par les cultures mixtes $369+160$, $369+302,369+368$.

Average acidity produced by mixed strains $369+160,369+302$, and $369+368$.

$b$ : - Somme moyenne des acidités produites par les cultures pures de L. bulgaricus 384 et de S. thermophilus 385.

Average sum of acid production by single strains of $\mathrm{L}$. bulgaricus 384 and $\mathrm{S}$. thermophilus 385 .

$\mathbf{\Delta - \Delta}$ Acidité moyenne produite par la culture mixte $385+384$.

Average acidity produced by mixed strains $385+384$.

$c$ : - Somme moyenne des acidités produites par les cultures pures de L. helveticus 303 et de S. thermophilus 160,302, 368.

Average sum of acid production by single strains of $\mathrm{L}$. helveticus 303 and $\mathrm{S}$. thermophilus 160,302 and 368 .

$\mathbf{\Delta}-\mathbf{\Delta}$ Acidité moyenne produite parles cultures mixtes $303+160,303+302,303+368$. Average acidity produced by mixed strains $303+160,303+362$, and $303+368$.

d: - Somme moyenne des acidités produites par les cultures pures de L. lactis 242 et de $\mathrm{S}$. thermophilus $160,302,368$.

Average sum of acid production by single strains of $\mathrm{L}$. lactis 242 and $\mathrm{S}$. thermophilus 160,302 and 368 .

$\mathbf{\Delta}-\mathbf{\Delta}$ Acidité moyenne produite par les cultures mixtes $242+160,242+302,242+368$. Average acidity produced by mixed strains $242+160,242+302$, and $242+368$. 


\section{Production de métabolites particuliers}

Le phénomène de coopération entre les bactéries lactiques se répercute également sur la production de métabolites dits secondaires. Une coopération entre souches peut être bénéfique à la production de composés d'arôme. HamDan et al. (1971) ont montré que L. bulgaricus produisait plus d'acétaldéhyde que $S$, thermophilus mais que la somme des productions d'acétaldéhyde en culture pure restait inférieure à la production correspondante de la culture mixte.

D'autres critères peuvent être employés pour montrer cette coopération, comme la mesure du temps de coagulation du lait, qui est plus court dans le cas d'une culture mixte que dans le cas de cultures pures (Koroleva et Kondratenko, 1982), ou comme l'évolution de la viscosité du lait (Galesloot et Hassing, 1973).

\section{B. Coopération par production de nutriments azotés}

Le lait est un milieu de culture relativement pauvre en composés azotés de bas poids moléculaire (acides aminés et peptides). Selon Thomas et Mills (1981) la plupart des acides aminés libres trouvés dans le lait sont en concentration trop faible pour obtenir des densités cellulaires importantes. Par exemple, il n'y aurait respectivement que 34 et $27 \%$ des concentrations de leucine et d'arginine requises pour une croissance maximale de la plupart des streptocoques lactiques. Cette carence en acides aminés libres a été également soulignée par MARSHALL et LAW (1984).

Il est maintenant bien connu que l'apport exogène d'acides aminés (PETTE et Lolkema, 1950b ; Bracquart et Lorient, 1977 ; Shankar et Davies, 1977a ; Bracquart et al., 1978) ou de peptides (Desmazeaud et Devoyod, 1970 ; Desmazeaud et Hermier, 1972 ; Bracquart et Lorient, 1979) a un effet stimulant sur la production d'acide des streptocoques thermophiles. D'autre part, l'hydrolyse et l'utilisation des protéines du lait comme source d'azote ont été clairement démontrées. Des protéines du lait marquées au ${ }^{14} \mathrm{C}$ sont utilisées et leur radioactivité est suivie dans les protéines bactériennes lors de la croissance de $S$. cremoris dans le lait. L'activité spécifique des protéines cellulaires augmente, indiquant que les protéines du lait deviennent une source d'azote de plus en plus importante avec l'accroissement de la densité cellulaire (Thomas et Mills, 1981).

On peut s'attendre à ce que la coopération entre souches intervienne dans le cas des cultures mixtes, du fait des fortes variations de l'activité protéolytique d'une espèce à une autre, ou même, d'une souche à une autre (LAw et Kolstad, 1983). Par exemple, Shankar et Davies (1977b) ont démontré le rôle joué par $L$. bulgaricus dans la stimulation de $S$. thermophilus, en utilisant des filtrats de culture du lactobacille ayant poussé sur du lait. Les fractions peptidiques, obtenues à partir de ces filtrats par chromatographie échangeuse d'ions, par filtration sur gel et par chromatographie sur papier, étaient fortement stimulantes pour $S$. thermophilus, sans toutefois contenir d'acides aminés. 
Hickey et al. (1983), Miller et Kandler (1967) et RadKe-Mitchell et SANDINE (1984) ont étudié la faculté des lactobacilles, de produire dans le milieu de culture, des acides aminés à partir de caséinate de sodium, et ils ont constaté que tous les lactobacilles testés possédaient une aminopeptidase générale (EC. 3.4.11,11). Les streptocoques thermophiles n'ayant pas d'enzyme protéolytique extracellulaire, cela explique la stimulation de croissance observée par apport d'acides aminés ou de peptides (Desmazeaud, 1983a). Cette production d'acides aminés par les lactobacilles a été également constatée par RADKe-Mitchell et SANDINE (1984) dans le yoghourt où les acides aminés libres représentent $1 \%$ du total des protéines, soit une augmentation des taux allant de 6 à $24 \mathrm{mg} / 100 \mathrm{ml}$. Comme, de son côté, $S$. thermophilus est doté de peptide-hydrolases intracellulaires de spécificité générale (Desmazeaud, 1983b), il peut utiliser les peptides exogènes comme source d'acides aminés.

Thomas et MiLs (1981) ont souligné l'importance des protéinases des levains mésophiles, en étudiant la croissance dans du lait de souches défi-

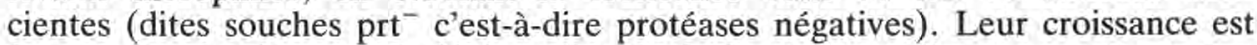
fortement stimulée par l'addition d'un hydrolysat de caséines, ce qui suggère que la croissance de tels organismes est stimulée, dans le lait, par les produits de la protéolyse des souches $\mathrm{prt}^{+}$. HEAP et Richardson (1985) ont confirmé ce phénomène, en constatant que les souches $\mathrm{prt}^{-}$n'atteignaient une densité cellulaire normale que si des acides aminés ou des peptides étaient ajoutés au lait. D'une part, ces auteurs observent que chez les souches prt $^{-}$la quantité de protéines solubles reste plus élevée et la production d'azote non protéique reste plus basse que chez les souches $\mathrm{prt}^{+}$. Ils en déduisent que ces souches prt ${ }^{-}$ auraient une activité peptidasique plus faible que celle des souches normales. Comme les levains mixtes commerciaux contiennent des mélanges de souches normales, c'est-à-dire $\mathrm{prt}^{+}$et de souches $\mathrm{prt}^{-}$, en quantité non négligeable, cela suggère que les souches normales, ont un effet stimulant sur la croissance des autres souches. ThомAs et Mills (1981) attribuent d'ailleurs la stimulation de $S$. thermophilus par $L$. bulgaricus à un taux de protéases plus élevé chez le lactobacille, le comportement de $S$. thermophilus serait alors analogue aux souches $\mathrm{prt}^{-}$de $S$. cremoris.

\section{Coopération par modification des conditions physiologiques du milieu}

Etant donné que le lait n'est pas un milieu de culture optimal pour les bactéries lactiques, il est évident que des modifications de conditions physiologiques peuvent avoir un rôle bénéfique pour les souches. Nous ne reviendrons pas sur la modification de la teneur en acides aminés ou en peptides du lait, mais nous nous attacherons aux conséquences de la modification du $\mathrm{pH}$ ou à la possibilité d'élimination des facteurs inhibiteurs.

\section{Influence de la modification du $p H$}

En étudiant l'influence de l'âge des cultures de lactobacilles sur la production d'enzymes protéolytiques, Ezzat et al. (1982) ont montré que l'activité spécifique d'exopeptidases des trois espèces étudiées ( $L$. bulgaricus, $L$. helveticus et $L$. lactis) augmentait pendant la phase exponentielle de croissance à 
$40^{\circ} \mathrm{C}$. L'augmentation de l'activité peptidasique, facteur de coopération comme nous venons de le voir pourrait être en relation avec la diminution du $\mathrm{pH}$ du milieu.

Cogan et al. (1981) ont mis en évidence le rôle du pH sur l'utilisation du citrate par les Leuconostoc, bactéries habituellement présentes dans les levains mésophiles producteurs d'arôme. Parallèlement, ces auteurs ont étudié le rôle du pH sur l'activité des enzymes productrices de composés d'arômes de certains produits laitiers : ces enzymes ont une activité maximale dans une zone de $\mathrm{pH}$ voisine de 5,5. Cette augmentation d'activité explique l'utilisation avantageuse de ces bactéries en culture mixte avec $S$. cremoris et/ou $S$. lactis (Marshall et LaW, 1984).

Ces deux études montrent que la diminution de $\mathrm{pH}$, plus rapide et plus accentuée lorsque l'on a affaire à une culture mixte, a certainement un rôle bénéfique sur au moins une des deux souches; elle pourrait intervenir en augmentant la force proton-motrice des bactéries donc en augmentant l'énergie métabolisable par l'intermédiaire du gradient de potentiel chimique du lactate (Konings et OtTo, 1983). L'importance de ce phénomène sera développée plus loin.

\section{Elimination de composés inhibiteurs}

Les bactéries lactiques sont des organismes microaérophiles, voire strictement anaérobies pour certaines. Dans tous les cas, tout facteur diminuant la quantité d'O$_{2}$ dissous dans le milieu de culture stimule leur croissance et favorise la production d'acide. SHEKAR et BHAT (1983) ont montré que les bactéries lactiques induisaient, à des degrés divers, une diminution du taux d'oxygène dans le lait. Leur incubation était en effet suivie d'une diminution de la concentration en oxygène et en radicaux sulfhydryles libres. Comme un échantillon témoin, ramené à la même acidité par addition d'acide lactique, ne montre pas ce phénomène, les auteurs en ont conclu que l'oxydation des groupes sulfhydryles libres par l'oxygène est catalysée par le métabolisme des bactéries lactiques. Les différences entre les cinétiques de diminution de l'oxygène d'une part, et la sensibilité des souches au facteur toxique oxygène d'autre part, peuvent être à l'origine d'une coopération entre les souches. KANBE et UCHIDA (1985) ont confirmé ce phénomène en montrant que des cellules de Pediococcus halophilus consommaient de l'oxygène, à des vitesses spécifiques variant de 5,52 à $6,59 \mathrm{nmol} / \mathrm{mn} . \mathrm{mg}$ de poids $\mathrm{sec}$, avec du L-lactate comme substrat.

Nous verrons dans la seconde partie que le peroxyde d'hydrogène peut aussi inhiber les bactéries lactiques. ReITER (1978) a montré que l'addition d'agents réducteurs comme la cystéine réduisait le peroxyde d'hydrogène et annulait donc l'inhibition. L'activité protéolytique des lactobacilles peut donc interférer avec ce composé (on a vu qu'il y avait augmentation du taux d'acides aminés libres sous leur action) et, ce faisant, lever l'inhibition.

L'activité inhibitrice des acides gras sur la croissance des streptocoques, des lactobacilles et des Leuconostoc a été constatée à plusieurs reprises. PoznANSKI et al. (1968) ont montré que l'acide oléique, qui inhibe la croissance et la production d'acide de $L$. helveticus, est, par contre, utilisé en grandes quantités par $S$. lactis. Il y a donc encore là possibilité de coopération. 


\section{Autres phénomènes pouvant permettre une coopération}

A la suite des travaux d'Auclair et PORTMANN (1958), consacrés aux effets stimulants du chauffage du lait sur la croissance ultérieure de souches de bactéries lactiques, GalesLoot et al. (1968) ont étudié l'influence des conditions de culture sur l'acidité produite par un mélange de souches de $L$. bulgaricus et $S$. thermophilus. Une souche de $S$. thermophilus est incubée dans du lait écrémé chauffé $10 \mathrm{mn}$ à $90^{\circ} \mathrm{C}$, sous atmosphère d'azote. A différents stades de la croissance, le streptocoque est éliminé par chauffage à $80^{\circ} \mathrm{C}$. $L$. bulgaricus est alors incubé, et l'acidité produite est mesurée par titration à la soude $0,1 \mathrm{~N}$. L'activité acidifiante, que ces auteurs ont obtenue, est alors comparable à celle qui est observée en ajoutant de l'acide formique au mélange de souches cultivées sous air. Le phénomène a été confirmé par d'autres chercheurs, l'acide formique est stimulant quand il est présent dans le milieu de culture à des taux d'environ $32 \mathrm{mg} / \mathrm{l}$ de culture (Accolas et al., 1971 ; Shankar et Davies, 1978). Higashio et al. (1978) mettent en évidence un effet synergique des acides formique et pyruvique sur la stimulation. Accolas et al. (1971) soulignent l'hypothèse selon laquelle l'acide formique serait impliqué dans la synthèse de l'adénine, composé stimulant la croissance (Auclair et Portmann, 1955). Il a été aussi montré, en séparant les acides gras volatils d'une culture de streptocoques par chromatographie, et en testant l'activité stimulante des fractions, que l'acide formique se trouvait dans le milieu de culture à des taux d'environ $32 \mathrm{mg} / 1$ de culture (GalesLoot et al., 1968). Veringa et al. (1968) sont ceux qui ont été le plus loin dans cette recherche. S'ils montrent bien la présence d'acide formique dans les échantillons prélevés en fin de culture, ceux-ci ne donnent pas la quantité initiale d'acide formique dans le lait qu'ils ont utilisé (chauffé à $90^{\circ} \mathrm{C}$ pendant $10 \mathrm{mn}$ ). D'autre part, aucune cinétique de production d'acide formique par $S$. thermophilus n'a jamais été publiée. On peut donc se demander si $S$. thermophilus stimule $L$. bulgaricus par la production de ce composé !

Driessen et al. (1982), en étudiant l'effet du taux de dilution sur $L$. bulgaricus cultivé en continu à $\mathrm{pH}$ constant, ont montré que l'augmentation de la concentration en $\mathrm{CO}_{2}$ dans le milieu stimulait la culture. Concomitamment, ces auteurs ont mis en évidence la production de $\mathrm{CO}_{2}$ par $S$. thermophilus et ont ainsi prouvé l'existence d'un autre facteur de coopération. ReITER et OrAm (1962) avaient déjà remarqué cet effet du $\mathrm{CO}_{2}$ lors de leur étude sur les besoins en vitamines de souches pures de streptocoques, et ils l'avaient imputé à l'intervention du $\mathrm{CO}_{2}$ dans la synthèse de l'acide aspartique. Tinson et al. (1982) interprètent la production de $\mathrm{CO}_{2}$ par $S$. thermophilus comme la conséquence de la décarboxylation, par une uréase, de l'urée présente dans le lait. Bien que Farrow et Collins (1984) ne mentionnent pas l'existence d'une uréase chez $S$. thermophilus comme caractère taxonomique représentatif de l'espèce de $S$, thermophilus, nos résultats (à paraître) vont dans le sens de ceux obtenus par Tinson et al. (1982).

On constate donc que l'étude des phénomènes de coopération est à poursuivre ; les données sont encore par trop fragmentaires et incomplètes (en particulier chez les bactéries lactiques mésophiles) et de nombreuses incertitudes subsistent, d'autant que la plupart des études métaboliques ont été effectuées avec des souches pures et que l'extrapolation aux cultures mixtes doit être faite avec prudence. 


\section{Les phénomènes d'inhibition}

\section{A. Mise en évidence}

Nous avons défini les phénomènes d'inhibition comme le résultat d'une interaction négative indirecte entre des souches cultivées ensemble. Il est évident que les critères d'observation sont les mêmes que ceux qui ont permis de mettre en évidence une coopération, c'est-à-dire essentiellement la croissance des souches et l'acidification du milieu. de culture.

Baribo et Foster (1951) ont étudié la croissance de $S$. lactis et de Lactobacillus casei, cultivés ensemble ou séparément dans du lait écrémé. Dans le cas de la culture mixte, la croissance du lactobacille était considérablement ralentie après $9 \mathrm{~h}$ d'incubation. Ces auteurs rapportent également que la production d'acide lactique par $L$. bulgaricus est considérablement amoindrie lorsque cette souche est cultivée avec $S$. lactis. L'étude des taux de croissance a également permis à DALY et al. (1970) de mettre en évidence l'inhibition d'une série d'organismes-tests choisis (divers Pseudomonas, Vibrio, Salmonella, Escherichia coli et Clostridium perfringens) par $S$. lactis subsp. diacetylactis. Lorsqu'une des souches tests était incubée dans du lait stérile avec $S$. lactis subsp. diacetylactis, soit à $21^{\circ} \mathrm{C}$, soit à $30^{\circ} \mathrm{C}$, pendant $48 \mathrm{~h}$, l'organisme-test montrait des difficultés à croître.

Collins (1961) a observé que lorsque différentes souches de streptocoques lactiques étaient cultivées ensemble dans du lait, l'une des souches dominait souvent les autres. Cela l'a donc conduit à étudier l'inhibition qui se manifeste entre différentes souches de streptocoques.

Il est intéressant de noter que ces phénomènes d'inhibition causés par les bactéries lactiques peuvent également s'exercer contre de nombreux organismes étrangers (staphylocoques, clostridies, streptocoques non lactiques, bactéries coliformes). Les causes de ces phénomènes d'inhibition sont nombreuses et la plus étudiée est vraisemblablement la production de bactériocines comme nous allons le voir maintenant.

\section{B. Production de bactériocines et d'antibiotiques}

La production de bactériocines par les bactéries lactiques est une cause d'inhibition connue depuis longtemps. Les bactériocines se définissent par:

- une activité antibactérienne au spectre d'action généralement étroit (même espèce ou espèce apparentée) ;

- la présence d'une partie peptidique ;

- une inactivation par les protéases ;

- leur thermostabilité.

De nombreuses substances inhibitrices ont été mises en évidence chez les bactéries lactiques. MatTick et Hirsch (1944) ont montré que certaines souches de $S$. lactis produisaient une substance ayant des propriétés inhibitrices 
marquées. Cette substance a été purifiée et dénommée «nisine ". De part son spectre d'action très étendu (aussi bien chez les lactiques qu'ailleurs), et en raison de sa puissance d'action, la "nisine » a été assimilée à un antibiotique. C'est aussi pour ces raisons que la nisine est employée comme agent de conservation dans certaines industries alimentaires (HurST, 1978). C'est certainement l'antibiotique qui a été le plus étudié parmi ceux que produisent des bactéries lactiques. HIRSCH (1951) a étudié la synthèse de cet antibiotique par $S$. lactis. Il a montré que sa synthèse se déroule en deux étapes. Il y aurait synthèse d'une protéine : la "pronisine », et ce précurseur serait converti en « nisine» au niveau de la membrane. Le polypeptide formé a un poids moléculaire de 3500 daltons, mais ne serait actif que sous forme de dimère. L'action inhibitrice n'apparaît qu'en fin de phase exponentielle de croissance de l'organisme producteur et passe par une adsorption de l'antibiotique sur les parois. Hurst (1978) a d'ailleurs montré que l'insensibilité de la souche productrice était reliée à la concentration intracellulaire des ions calcium. Une forte concentration en $\mathrm{Ca}^{2+}$ induirait des changements de conformation et il s'ensuivrait une inactivation de la «nisine », incapable alors de s'adsorber sur la paroi bactérienne. Le mode d'action de cet antibiotique sur les souches sensibles relève vraisemblablement de ce schéma.

De nombreuses autres substances inhibitrices ont été mises en évidence chez les bactéries lactiques (BABeL, 1977). Ainsi, Davey et Richardson (1981) ont confirmé que certaines souches de $S$. cremoris produisaient une substance inhibitrice, la diplococcine. DAveY (1981) a étudié l'effet de cette bactériocine sur la viabilité des cellules en phase logarithmique de croissance. Il a ainsi montré que la diplococcine était surtout active contre les souches de $S$. lactis et de $S$. cremoris, en observant une diminution rapide du nombre de cellules viables à $30^{\circ} \mathrm{C}$, avec une perte totale de viabilité après $3 \mathrm{~h}$. L'âge de la culture incubée a un rôle considérable, puisque des cellules en phase stationnaire de croissance, dans les conditions de l'expérience précédente, ne montrent qu'une diminution de deux logarithmes décimaux dans le nombre de survivants. Cela s'explique par le fait que la diplococcine agirait sur la synthèse d'ADN et d'ARN, en deux étapes.

$S$. thermophilus produirait également une bactériocine de faible poids moléculaire, thermorésistante, active contre des souches de $S$. lactis (PULUSANI et al., 1979 ; SMACZNY et Kramer, 1984) ; L. bulgaricus produirait de l'acidophiline (Shahani et al, , 1976, 1977). D'autres composés (lactocine B, lactocine 27) ont aussi été mentionnés (BAREFoot et KlaENHAMMER, 1981, 1983) ; UPRETI et Hinsdill, 1973, 1975). S. lactis subsp. diacetylactis élaborerait également une substance inhibitrice, la "lactostrepcine », qui est pleinement active dans une gamme de $\mathrm{pH}$ allant de 4,2 et 5,0 et qui a un spectre d'action restreint, limité à des Leuconostoc et à des L. helveticus (KozAK et al., 1978). Il semble d'ailleurs que l'existence de ces bactériocines ne soit pas reconnue par tous, comme l'est celle de la nisine ou celle de la diplococcine, car beaucoup de ces substances n'ont pas été suffisamment bien caractérisées. Une certaine confusion existe dans ce domaine. Par exemple, Spillmann et al. (1978) n'ont pas réussi à confirmer l'existence de l'acidophiline et d'un autre antibiotique produit par $L$. bulgaricus décrits précédemment par SHAHANI et al. (1976, 1977). Avec les mêmes souches, ils n'ont réussi à mettre en évidence, que l'effet inhibiteur de l'acide lactique. 


\section{Le système lactoperoxydase-thiocyanate-peroxyde d'hydrogène}

Ce mode d'inhibition met en jeu trois facteurs, dont deux sont naturellement présents dans le lait : la lactoperoxydase (EC 1.11.1.7.) issue de la glande mammaire des bovins et le thiocyanate (SCN) qui, provenant de l'alimentation du bétail, se retrouve dans le lait à des concentrations de 1 à 10 ppm (Reiter et HaRnvuld, 1984). Le troisième facteur est le peroxyde d'hydrogène, $\mathrm{H}_{2} \mathrm{O}_{2}$ qui, lui, provient du métabolisme des lactobacilles (DAHIYA et SPECK, 1968) ou des streptocoques (ReITER, 1978 ; Grufferty et Condon, 1983) cultivés en aérobiose partielle mais qui n'est pas naturellement présent dans le lait.

La lactoperoxydase se combine avec le peroxyde d'hydrogène pour oxyder le thiocyanate en un produit d'oxydation à courte durée de vie. Ce composé serait responsable des phénomènes d'inhibition de la croissance et de l'activité des bactéries lactiques (ORAM et REITER, 1966). Il semblerait que les streptocoques soient capables, au moins partiellement de neutraliser le produit d'oxydation du système lactoperoxydase-thiocyanate ou de réparer les dommages causés (ReIter et HARnvuld, 1984). Ceci expliquerait ainsi pourquoi le système n'est que bactériostatique contre les streptocoques et les lactobacilles, alors qu'il est bactéricide pour les bactéries coliformes, les Pseudomonas, etc. qui, eux, seraient incapables de surmonter l'inhibition.

Il apparaît donc que le peroxyde d'hydrogène peut être auto-inhibiteur. Cependant, toutes les bactéries lactiques ne produisent pas suffisamment de ce composé pour que le système lactoperoxydase-thiocyanate soit activé. Mais, dans le cas d'une culture séquentielle de plusieurs souches, une bactérie produisant peu de peroxyde d'hydrogène peut être inhibée par le système lactoperoxydase-thiocyanate qui a été activé par une autre souche. Ainsi GILLILAND et SPECK (1977) ont montré que Lactobacillus acidophilus est inhibé par $L$. bulgaricus lorsqu'il est ajouté dans le yoghourt conservé au froid. Comme l'incubation de cette souche dans du lait acidifié artificiellement n'aboutissait pas à une inhibition alors que l'addition de catalase au yoghourt levait l'inhibition observée, les auteurs en ont conclu que c'était bien le système lactoperoxydase-thiocyanate qui, activé par le peroxyde d'hydrogène produit par L. bulgaricus, inhibait la culture de L. acidophilus. ArchiBald et FrIDOVITCH (1981) ont mis en évidence une relation entre l'équipement en pseudocatalase, catalase, superoxyde dismutase ou $\mathrm{Mn}^{++}$et la résistance des bactéries lactiques à l'oxygène dissous dans le milieu de culture.

\section{Compétition vis-à-vis du substrat}

Lorsque plusieurs souches sont mises en culture dans un même milieu, elles entrent nécessairement en compétition, si elles utilisent le même substrat. C'est ce qui se passe avec les bactéries lactiques utilisant le lactose. HugENholtz et VeldKamp (1985) ont étudié les changements de composition de mélanges de souches de $S$. cremoris mises en culture continue dans du lait, changements qui sont les conséquences des différences entre les taux de croissance spécifiques maxima. Ces auteurs ont déduit de ces résultats une courbe représentant les relations théoriques entre le taux de croissance spécifi- 
que maximum et la concentration en lactose. Comme le lactose est en forte concentration dans le lait, il apparaît clairement qu'une des souches sera amenée à disparaître (fig. 2).

La compétition ne peut avoir lieu que sur une fraction du lactose. En effet, dans le cas de cocultures de $S$. thermophilus et $L$. helveticus, le streptocoque assimile mal le galactose (Thомas et Crow, 1983). De plus, $L$. helveticus assimile d'abord le glucose avant d'assimiler le galactose (TURNER et al., 1983). Il existe donc, au début de la fermentation, une utilisation simultanée du même substrat par deux souches différentes. Par la suite, seule l'activité de $L$. helveticus peut s'exprimer.

Ce type d'inhibition par compétition a été également analysé dans le cas de l'association de $S$. thermophilus avec $L$. bulgaricus (Moon et ReINBold, 1976). Dans les conditions optimales de stimulation de la production d'acide, c'est-à-dire à $37^{\circ} \mathrm{C}, S$. thermophilus croît plus rapidement que L. bulgaricus,

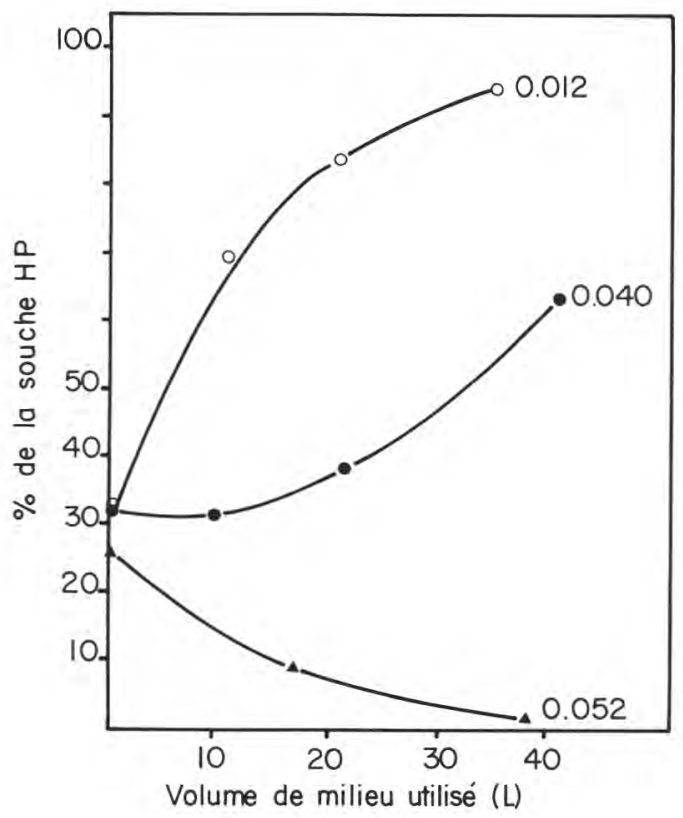

Fig. 2

Evolution du rapport de la souche $\mathrm{S}$. cremoris $H P$ à la souche $\mathrm{S}$. cremoris $M L 1$ en culture continue (d'après HUGENHOLTZ et VELDKAMP, 1985).

Evolution of the ratio of strain S. cremoris $H P$ to strain $\mathrm{S}$. cremoris $M L 1$ in continuous culture (from HUGENHOLTZ and VELDKAMP, 1985).

Les deux souches sont cultivées en chémostat, le lactose est en quantité limitante. La détermination du nombre de bactéries de chaque souche se fait par étalement sur gélose et incubation sous différentes atmosphères. (Les deux souches ne supportent pas le $\mathrm{CO}_{2}$ de la même manière).

The culture of the two strains is made in a chemostat, in which lactose is present at a limiting rate. Bacteria numeration is performed by spreading on gelose, and by incubating under different atmospheres (Each strain has his own way of enduring $\mathrm{CO}_{2}$ ). 
ce dernier se développant moins activement en culture mixte que lorsqu'il est cultivé seul. Cette inhibition du lactobacille a été interprétée, par les auteurs, comme le résultat d'une utilisation rapide de quelques nutriments essentiels par $S$. thermophilus, aux dépens du lactobacille. Cette hypothèse est d'ailleurs suggérée par le fait que la température optimale de croissance de $S$. thermophilus $\left(40-45^{\circ} \mathrm{C}\right)$ est plus proche de la température optimale de stimulation de la production d'acide $\left(37^{\circ} \mathrm{C}\right)$ que celle de $L$. bulgaricus $\left(45-50^{\circ} \mathrm{C}\right)$. Mais cet argument est-il suffisant ?

\section{E. Rejet de produits du catabolisme}

Peu d'informations sont disponibles sur les produits du métabolisme cellulaire susceptibles de limiter la croissance des bactéries lactiques. La production d'acide lactique est la cause la plus importante de l'inhibition de la croissance et de l'activité des bactéries lactiques. suivant :

L'acide lactique produit se trouve en solution et est sujet à l'équilibre

$$
\mathrm{CH}_{3}-\mathrm{CHOH}-\mathrm{COOH}+\mathrm{H}_{2} \mathrm{O} \rightleftharpoons \mathrm{CH}_{3}-\mathrm{CHOH}-\mathrm{COO}^{-}+\mathrm{H}_{3} \mathrm{O}^{+}
$$

En milieu acide la forme moléculaire domine, en milieu alcalin ou neutre la forme ionisée est quantitativement plus importante. Ces deux formes sont à l'origine de deux types d'inhibition, l'une d'elles devenant prédominante, suivant les conditions de $\mathrm{pH}$. Si le $\mathrm{pH}$ n'est pas maintenu constant, c'est l'ion $\mathrm{H}_{3} \mathrm{O}^{+}$qui est inhibiteur. Si le $\mathrm{pH}$ est régulé à un $\mathrm{pH}$ peu acide $(\mathrm{pH} 6,0$ par exemple), l'ion $\mathrm{CH}_{3}-\mathrm{CHOH}-\mathrm{COO}^{-}$est alors présent en quantité plus importante; dans ce cas, l'inhibiteur est proche d'une inhibition par excès de concentration saline, et ne relève plus de la concentration en ion $\mathrm{H}_{3} \mathrm{O}^{+}$. Ces deux systèmes d'inhibition sont très différents et peuvent ne pas avoir le même effet sur des cultures associées. Prenons l'exemple de cocultures de $S$. thermophilus avec $L$. bulgaricus:

- si le $\mathrm{pH}$ n'est pas régulé, $L$. bulgaricus continue à croître après arrêt de la croissance de $S$. thermophilus (Accolas et al., 1977);

- si le $\mathrm{pH}$ est régulé (entre 5,5 et 6,5), la croissance des deux souches s'arrête en même temps (résultats à paraître).

A pH régulé, l'inhibition par les ions $\mathrm{H}_{3} \mathrm{O}^{+}$qui est différente pour les deux souches disparaît; par contre, elle laisse place à un autre facteur limitant qui peut être un substrat manquant ou une inhibition par le lactate de sodium.

La principale modification des conditions physico-chimiques du milieu, responsable de phénomènes d'inhibition est très certainement le gradient de protons dû à la production d'acide lactique (fig. 3). En effet, le taux de croissance que peuvent atteindre certaines bactéries lactiques est considérablement augmenté si le $\mathrm{pH}$ du milieu de culture est maintenu constant (BERGERE, 1968; Gilliland et SPECK, 1968). Le phénomène a été constaté par de nombreux autres chercheurs.

Konings et Otтo (1983), Otro et al. (1983) ont analysé les conséquences des variations de milieu sur la contribution de l'efflux de lactate à l'énergie métabolique de $S$. cremoris en culture discontinue, par l'étude de la force 
proton-motrice et du gradient de lactate au cours de la croissance. Le rapport gradient de lactate/force proton-motrice diminue pendant la croissance de la souche. Cette diminution du rapport indique une baisse de la stoechiométrie $\mathrm{H}^{+} /$lactate, et donc une diminution de la contribution de l'efflux de lactate à l'énergie métabolique.

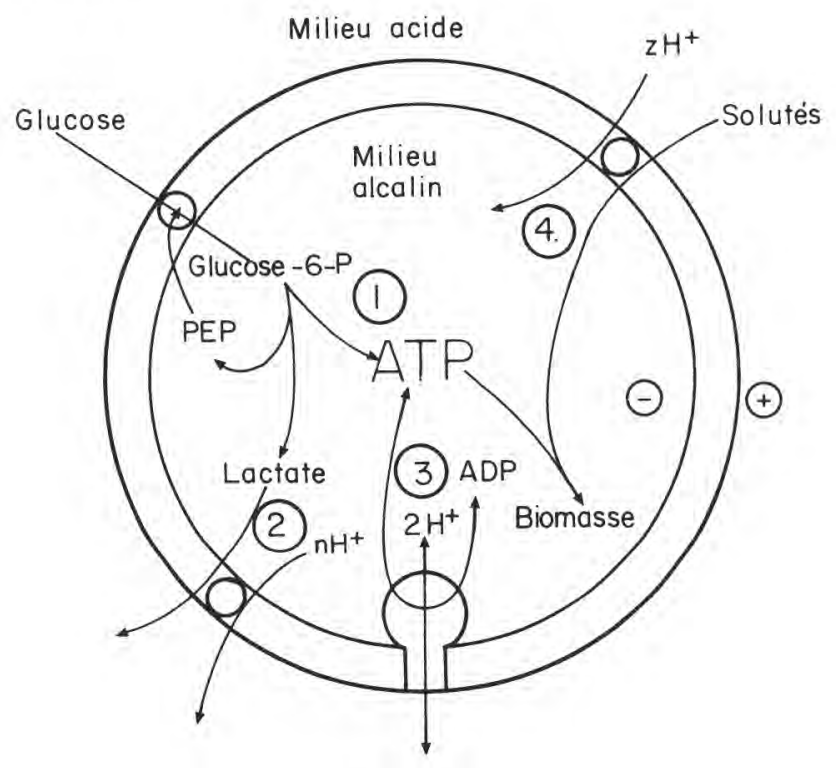

Fig. 3

Schéma du processus de synthèse et d'utilisation de l'énergie chez les streptocoques (d'après KonINGS et OTTO, 1983).

Scheme of metabolic energy-generating and energy-consuming process in streptococci (from KONINGS and OTTO, 1983).

Quatre systèmes liés à la synthèse d'ATP sont visibles sur ce schéma:

Four systems related to ATP synthesis are emphasized on this scheme.

1) la synthèse d'ATP à partir du substrat;

ATP synthesis from substrate;

2) le couplage de la sortie d'ions $\mathrm{H}^{+}$avec la sortie d'ions lactate $\left(2 \mathrm{H}^{+}\right.$par lactate) ; coupling of lactate and protons outflows $\left(2 \mathrm{H}^{+}\right.$per lactate);

3) le couplage de la sortie de protons avec consommation d'ATP ou d'entrée de protons avec production d'ATP;

coupling of protons outflow or inflow with respectively ATP consumption or production;

4) le couplage de l'entrée de solutés avec une entrée de protons. coupling of solutes and protons inflows.

La sortie de protons par le système (2) couplé avec l'entrée de cet ion par le système (3) aboutit à la synthèse d'ATP, tant que la concentration interne en lactate est plus élevée que sa concentration externe.

Protons outflow through system (2) coupled with its inflow through system (3) results in ATP synthesis, as long as inside lactate concentration remains higher than outside lactate concentration. 
Ces mêmes auteurs ont montré, que lorsque le $\mathrm{pH}$ du milieu diminue, l'organisrue en croissance maintient son $\mathrm{pH}$ interne à une valeur constante de 6,6 , ce qui implique donc la formation d'un gradient de $\mathrm{pH}$. Or, à la fin de la phase exponentielie de croissance, le $\mathrm{pH}$ ne peut plus être maintenu constant, vraisemblablement par manque d'ATP. Il chute brutalement (fig. 4), le gradient de $\mathrm{pH}$ disparaît, les activités enzymatiques diminuent. Dans ces conditions, la forte acidité du milieu de culture influe sur l'activité, entre autres, des enzymes protéolytiques. Accolas et al. (1980) signalent que l'activité de l'hexokinase, d'une souche de $S$. thermophilus est ralentie par les bas $\mathrm{pH}$, à la différence d'autres enzymes de la glycolyse. Cette diminution d'activité pourrait freiner la poursuite de la glycolyse et, en définitive, affecter la croissance de la souche.

D'autres bactéries lactiques sont mieux armées pour continuer à croître à de bas $\mathrm{pH}$. Rappelons que la production d'acide lactique est couplée à la réoxydation du NADH en NAD nécessaire au bon fonctionnement de la glycolyse.

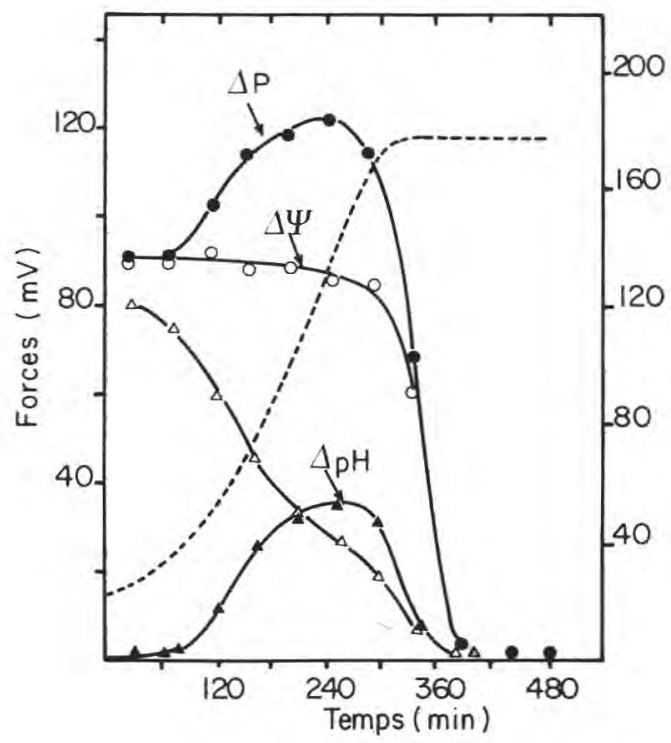

Fig. 4

Evolution $d u \mathrm{pH}$, de la force proton-motrice et du gradient de lactate chez $\mathrm{S}$. cremoris pendant la croissance (d'après KonINGS et OTTO, 1983). Croissance en culture discontinue sur milieu complexe avec du lactose comme source d'énergie.

Evolution of the $\mathrm{pH}$, the proton motive force and the lactate gradient in $\mathrm{S}$. cremoris during growth (from KoNINGS and OTTO, 1983). Growth in batch cultures on complex medium with lactose as sole energy source.

Force proton motrice $(\bullet)$, différence de potentiel membranaire $(\bigcirc)$, gradient de $p H(\nabla)$, gradient de lactate $(\triangle)$, concentration en protéines cellulaires (...).

Proton motive force $(\bullet)$, membrane potential $(\mathrm{O}), \mathrm{pH}$ gradient $(\nabla)$, lactate gradient $(\Delta)$, cell protein concentration (...). 
Certains microorganismes ( $S$. lactis subsp. diacetylactis) ont un autre moyen de réoxyder le NADH à partir du pyruvate. Ils forment du 2-3 butylène glycol, du diacétyle et de l'acétoine (SEPCKMAN et Collins, 1968) qui sont tous des composés neutres. Leur synthèse est aussi couplée à la réaction de réoxydation du NADH. Ces bactéries disposent ainsi de voies métaboliques qui leur évitent de transformer tout le pyruvate en acide lactique sans bloquer la glycolyse. Cette possibilité semble d'ailleurs s'exprimer principalement à $\mathrm{pH}$ bas (Collins, 1972). De plus, le 2-3 butylène glycol peut être reconsommé par la suite. De telles régulations sont à même de modérer l'effet inhibiteur du métabolisme d'autres souches dans des cultures mixtes.

Wright et Klaenhammer (1984) ont mis en évidence l'effet inhibiteur du phosphate sur la croissance et la production d'acide de L. bulgaricus, à des concentrations de l'ordre de 1 à $2 \%$ dans le lait. Ce phénomène d'inhibition par des ions et son influence sur les cultures mixtes ont été très peu étudiés, bien que la modification des conditions ioniques du milieu de culture des bactéries lactiques ait certainement un rôle important sur la croissance de ces organismes. Il est évident que l'inhibition de la croissance est liée à la concentration en ions (par exemple, l'ion lactate). L'utilisation de milieux ayant des concentrations ioniques élevées va favoriser ces inhibitions.

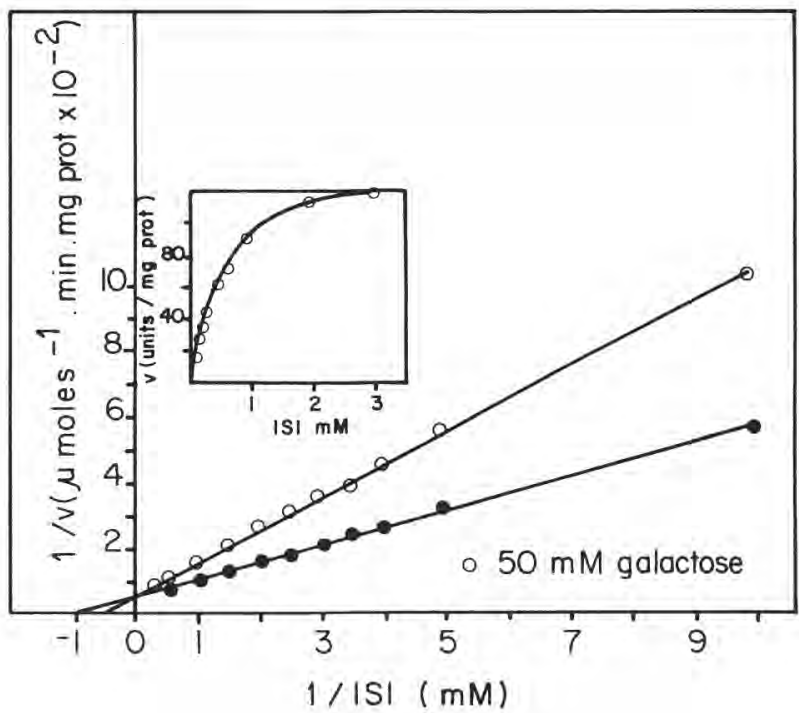

Fig. 5

Détermination du $K_{i}$ du galactose (d'après GREENBERG et MAHOMEY, 1982). Le $K_{i}$ a été déterminé par l'étude de l'hydrolyse de l'ONPG par la $\beta$-galactosidase de S. thermophilus dans un tampon phosphate $\mathrm{pH}=7,0$ à $37^{\circ} \mathrm{C}$.

$K_{i}$ determination of galactose (from GREENBERG and MAHOMEY, 1982). $K_{i}$ was determined by studying the ONPG hydrolysis by $\mathrm{S}$. thermophilus $\beta$-galactosidase in a phosphate buffer pH 7.0 at $37^{\circ} \mathrm{C}$. 
Il a été établi que le galactose est responsable d'une inhibition de croissance de souches de $S$. thermophilus (Somkuti et Steinberg, 1979). L'étude de l'hydrolyse de l'ortho-nitrophényl- $\beta$-galactopyranoside (ONPG), en tampon phosphate de potassium, a permis à GREENBERG et MAHONEY (1982) de montrer que le galactose est un inhibiteur compétitif de la $\beta$-galactosidase de $S$. thermophilus, de paramètre cinétique $\mathrm{K}_{\mathrm{i}}=60 \mathrm{mM}$ (fig. 5 ). Compte tenu du fait que peu de galactose est consommé par $S$. thermophilus dans le cas de cocultures de cette espèce avec d'autres à $\mathrm{pH}$ constant, cela peut être une explication de l'inhibition de ces bactéries en fín de croissance. D'autant que dans le cas d'une telle culture, le taux de galactose dans le milieu est plus élevé que dans le cas de souches isolées.

L'étude de l'activité antimicrobienne de souches de $S$. lactis subsp. diacetylactis et de Leuconostoc cremoris (BRANEN et al., 1975) a montré que certaines souches de Pseudomonas étaient inhibées, et que les acides organiques issus du métabolisme de ces deux bactéries lactiques étaient des agents inhibiteurs. Cependant, l'action de ces acides sur les souches de bactéries lactiques n'a malheureusement pas été recherchée. Il y a donc une possibilité d'inhibition qui serait à confirmer.

\section{Conclusion}

La coopération et l'inhibition entre les bactéries lactiques utilisées en industrie laitière mettent en jeu, nous l'avons vu, des mécanismes de diverses natures. Il s'ensuit deux conséquences.

- S'il s'agit d'une coopération, l'acidification sera plus rapide ; il en sera de même de l'obtention des propriétés rhéologiques recherchées. Inversement, s'il y a inhibition, on observera un retard d'acidification.

- La seconde conséquence est qu'un levain complexe utilisé en industrie n'aura pas, presque à coup sûr, la même composition lorsqu'il est cultivé pour la première fois et après un certain nombre de repiquages. Le rapport des souches composant le levain utilisé peut être modifié, et ces modifications peuvent altérer les performances du levain. Ces phénomènes posent évidemment des problèmes considérables en industrie, comme la régularité d'acidification, la régularité de l'obtention des propriétés conduisant aux qualités du produit final (arômes, goût, texture...). Cela signifie donc que l'emploi des levains complexes en industrie laitière, bien qu'il présente des avantages (résistance aux phages, caractéristiques aromatiques de certains fromages), n'est pas sans contraintes. Ces contraintes sont d'autant plus pesantes que l'empirisme fait encore trop souvent loi dans l'emploi de ces levains (presque, exclusivement, dans le cas des mésophiles type «Flora Danica »). En effet, beaucoup reste à faire dans l'étude des phénomènes de coopération et d'inhibition et de trop nombreuses affirmations ne sont encore que le fruit d'hypothèses insuffisamment vérifiées ou d'extrapolations fondées sur l'étude de souches pures. Or, la maîtrise des levains passe par la connaissance des paramètres régulant les métabolismes des souches utilisées en mélange dans les levains, celle-ci incluant, bien entendu, les phénomènes de coopération et d'inhibition qui peuvent se produire simultanément. 
Ces contraintes ne pourront pas être surmontées autrement que par une recherche pluridisciplinaire consacrée à la conduite des cultures et au fonctionnement des régulations des systèmes biologiques utilisés ainsi qu'à la connaissance de leur support génétique. Ce n'est qu'à partir de ces connaissances de base qui nous manquent que l'on pourra savoir si une seule souche pourra donner naissance à un fromage ayant des qualités organoleptiques données, ou si la conduite raisonnée de cultures mixtes est mieux appropriée à cette fin. Etant donné la variété des fromages, il semble que ces deux stratégies de recherches envisagées pour améliorer et/ou régulariser l'obtention d'une bonne qualité pourra dépendre du type de fromage et de ce fait, ces deux voies de recherches ne sont pas contradictoires.

Reçu le 15 mai 1986.

Accepté pour publication le 3 septembre 1986.

\section{Remerciements}

Nous remercions J.-P. AcColas pour ses suggestions et critiques lors de la rédaction du manuscrit, ainsi que $M^{\text {me }}$ MaRTIN pour la dactylographie du texte.

\section{Références bibliographiques}

Accolas J.-P., Veaux M., Auclair J., 1971. Etude des interactions entre diverses bactéries lactiques thermophiles et mésophiles, en relation avec la fabrication des fromages à pâte cuite. Lait, 51, 249-272.

Accolas J.-P., Bloquel R., Didienne R., Regnier J., 1977. Propriétés acidifiantes des bactéries lactiques thermophiles en relation avec la fabrication du yoghourt. Lait, 57, 1-23.

Accolas J.-P., Hemme D., Desmazeaud M.J., Vassal L., Boulllanne C., Veaux M., 1980. Les levains lactiques thermophiles : propriétés et comportement en technologie laitière. Lait, 60, 487-524.

Archibald F.S., Fridovich I., 1981. Manganese, superoxide dismutase, and oxygen tolerance in some lactic acid bacteria. J. Bacteriol., 146, 928-936.

Auclair J., Portmann A., 1955. Influence du chauffage du lait sur le développement des bactéries. Ann. Technol. Agric., 4, 121-131.

Auclair J., Portmann A., 1958. Influence du chauffage du lait sur le développement des bactéries. Ann. Technol. Agric., 6, 129-150.

Babel F.J., 1977. Antibiosis by lactic culture bacteria. J. Dairy Sci., 60, 815-821.

Barefoot S.F., KLAenhammer T.R,, 1981. Identification of a bacteriocin produced by Lactobacillus acidophilus. J. Dairy Sci., 64 (sup. 1), 51.

Barefoot S.F., Klaenhammer T.R., 1983. Detection and activity of lactocin B, a bacteriocin produced by L. acidophilus. Appl. Environ. Microbiol., 45, 1808-1815.

Baribo, L.E., Foster M.E., 1951. The production of a growth inhibitor by lactic streptococci. J. Dairy Sci., 60, 1135-1144.

Bautista E.S., DahiYa R.S., Speck M.L., 1966. Identification of compounds causing symbiotic growth of Streptococcus thermophilus and Lactobacillus bulgaricus in milk. J. Dairy Res., 33, 299-307. 
Bergere J.-L., 1968. Production massive de cellules de streptocoques lactiques. Lait, 48, 131-139.

Bracquart P., Lorient D., 1977. Effets des acides aminés sur la croissance de Streptococcus thermophilus. Milchwissenschaft, 32, 221-224.

Bracquart P., Lorient D., Alais C., 1978. Effet des acides aminés sur la croissance de Streptococcus thermophilus. II. Etude sur cinq souches. Milchwissenschaft, 33, 341-344.

Bracquart P., Lorient D., 1979. Effet des acides aminés sur la croissance de Streptococcus thermophilus. III. Peptides comportant Glu, His et Met. Milchwissenschaft, 34, 676-679.

Branen A.L., Go H.C., Genske R.P., 1975. Purification and properties of antimicrobial substances produced by Streptococcus diacetylactis and Leuconostoc citrovorum. J. Food. Sci., 40, 446-450.

Cogan T.M., 1980. Les levains lactiques mésophiles. Lait, 60, 397-425.

Cogan T.M., O'Dowd M., Mellerick D., 1981. Effects of $\mathrm{pH}$ and sugar on acetoin production from citrate by Leuconostoc lactis. Appl. Environ. Microbiol., 41, 1-8.

Collins E.B., 1961. Domination among strains of lactic streptococci with attention to antibiotic production. Appl. Microbiol., 9, 200-205.

Collins E.B., 1972. Biosynthesis of flavor compounds by microorganisms. J. Dairy Sci., 55, 10221028 .

DAHIYA R.S., SPECK M.L., 1968. Hydrogen peroxide formation by lactobacilli and its effect on Staphylococcus aureus. J. Dairy. Sci., 51, 1568-1572.

Daly C., Sandine W.E., Elliker P.R., 1970. Associative growth and inhibitory properties of Streptococcus diacetylactis. J. Dairy Sci., 53, 637-638.

DAVEY G.P., 1981. Mode of action of diplococcin, a bacteriocin from Streptococcus cremoris 346. N.Z.J. Dairy Sci. Technol., 16, 187-190.

Davey G.P., Richardson B.C., 1981. Purification and some properties of diplococcin from Streptococcus cremoris 346. Appl. Environ. Microbiol., 41, 84-89.

Desmazeaud M., 1983a. Comment les bactéries lactiques se comportent-elles dans le lait ? Techn. lait., (976), 11-18.

Desmazeaud M., 1983b. L'état des connaissances en matière de nutrition des bactéries lactiques. Lait, 63, 267-316.

Desmazeaud M., Devoyod J.-J., 1970. Action stimulante des microcoques caséolytiques sur les bactéries lactiques thermophiles. Mise en évidence de la nature peptidique des substances stimulantes. Ann. Biol. anim. Biochim. Biophys., 10, 413-430.

Desmazeaud M., Hermier J., 1972. Isolement et détermination de la composition qualitative des peptides issus de la caséine, stimulant la croissance de Streptococcus thermophilus. Eur. J. Biochem., 28, 190-198.

Desmazeaud M.J., Hermier J.H., 1973. Effets de fragments peptidiques de glucagon vis-à-vis de la croissance de Streptococcus thermophilus. Biochimie, 55, 679-684.

Driessen F.M, Kingma F., Stadhouders J,, 1982. Evidence that Lactobacillus bulgaricus in yoghurt is stimulated by carbon dioxide produced by Streptococcus thermophilus. Neth Milk Dairy J., 36, 135-144.

Ezzat N., El Soda M., Desmazeaud M.J., Ismall A., 1982. Peptidehydrolases from the Thermobacterium group of lactobacilli. II. Physiological factors and enzyme production. Milchwissenschaft, 37, 666-668.

Farrow J.A.E., Collins M.D., 1984. DNA base composition, DNA-DNA homology and longchain fatty acid studies on Streptococcus thermophilus and Streptococcus salivarius. J. Gen. Microbiol., 130, 357-362.

Frederickson A.G., 1977. Behaviour of mixed cultures of microorganisms. Annu. Rev. Microbiol., $31,63-87$.

Galesloot T.E., Hassing F., Veringa H.A., 1968. Symbiosis in yoghurt. I. Stimulation of Lactobacillus bulgaricus by a factor produced by Streptococcus thermophilus. Neth. Milk Dairy $J$, , 22, 50-63.

Galesloot T.E., Hassing F., 1973. Further investigations concerning the consistency of yoghurt. NIZO Mededelingen, 7, 15-33. 
Gilliland S.E., Speck M.L., 1968. D-leucine as an auto-inhibitor of lactic acid streptococci. J. Dairy Sci., 51, 1573-1578.

Gillrland S.E., SePCK M.L., 1977. Instability of Lactobacillus acidophilus in yoghurt. J. Dairy Sci., 60, 1394-1398.

Greenberg N.A., Mahoney R.R., 1982. Production and characterization of $\beta$-galactosidase from Streptococcus thermophilus. J. Food Sci., 47, 1824-1825.

Grufferty R.C., Condon S., 1983. Effect of fermentation sugar on hydrogen peroxide accumulation by Streptococcus lactis C10. J. Dairy Res., 50, 481-489.

Hamdan I.Y., Kunsman J.E., Deane D.D., 1971. Acetaldehyde production by combined yoghurt cultures, J. Dairy Sci., 54, 1080-1082.

Heap H.A., Richardson G.H., 1985. The proteolytic effect of fast-coagulating and slow-coagulating strains of Streptococcus cremoris. N.Z.J. Dairy Sci. Technol, 20, 155-161,

Hemme D.H., Schmal V., Auclair J.E., 1981. Effect of addition of extracts of thermophilic lactobacilli on acid production by Streptococcus thermophilus in milk. J. Dairy Res., 48, 139148.

Hickey M.W., Hillıer A.J., JAgo G.R., 1983. Peptidase activities in lactobacilli. Aust. J. Dairy Technol., 38, 118-123.

Higashio K., Кiкuchi T., Furuichi E., 1978. Symbiose entre Lactobacillus bulgaricus et Streptococcus thermophilus dans le yoghourt. $X X^{e}$ Congr. Int. Lait, Paris, F, 522-523.

Hirsch A., 1951. Growth and nisin production of a strain of Streptococcus lactis. J. Gen. Microbiol., 5, 208-211.

Hugenholtz J., VeldKAMP H., 1985. Competition between different strains of Streptococcus cremoris. FEMS Microbial. Ecol., 31, 57-62.

HURST A., 1978. Nisin : its preservative effect and function in the growth cycle of the producer organism. In : Streptococci, Skinner and Quesnel (ed.), Academic Press Inc., Londres, 297314.

Kanbe C., Uchida K., 1985. Oxygen consumption by Pediococcus halophilus. Agric. Biol. Chem., 49, 2931-2937.

Konings W.N., Otto R., 1983. Energy transduction and solute transport in streptococci. Antonie Van Leeuwenhoek, J. Microbiol. Serol., 49, 247-257.

Koroleva N.S., Kondratenko M.S., 1982. Symbiotic starters Streptococcus thermophilus and Lactobacillus bulgaricus. XXI Int. Dairy Congr., Moscou, 146.

KozAK W., BaRdowSKI J., DoBRZANSKI W.T., 1978. Lactostrepcins-acid bacteriocins produced by lactic streptococci. J. Dairy Res., 45, 247-257.

Law B.A., Kolstad J., 1983. Proteolytic systems in lactic acid bacteria. Antonie Van Leeuwenhoek, J. Microbiol. Serol., 49, 225-245.

Lawrence R.C., Heap H.A., Gilles J., 1984. A controlled approach to cheese technology. J. Dairy Sci., 67, 1632-1645.

Marshall M.E., LAW B.A., 1984. The physiology and growth of dairy lactic acid bacteria. In : Advances in the microbiology and biochemistry of cheese and fermented milk, Davies F.L. and Law B.A. (ed.), Elsevier Applied Science Publishers, Londres, 67-98.

Matrick A.T.R., HiRsch A., 1944. A powerful inhibitory substance produced by group N streptococci. Nature, 154, 551.

Miller 1., Kandler O., 1967. Eiweissabbau und Anreicherung freier Aminosäuren durch Milchsäurebakterien in Milch. II. Die Anreicherung freier Aminosäuren durch Thermobakterien. Milchwissenschaft, 22, 469-480.

Moon N.J., Reinbold G.W., 1976. Commensalism and competition in mixed cultures of Lactobacillus bulgaricus and Streptococcus thermophilus. J. Milk Food Technol., 39, 337-341.

Oram J.D., Reiter B., 1966. The inhibition of Streptococcus by lactoperoxydase, thiocyanate and hydrogen peroxide. II. The oxidation of thiocyanate and the nature of the inhibitory compound. Biochem. J., 100, 382-388.

OtTo R., Brink B., Veldkamp H., Konings W.N., 1983. The relation between growth rate and electrochemical proton gradient of Streptococcus cremoris. FEMS Microbiol. Lett., 16, 69-74. 
Pernodet G., 1984. Technologie comparée des différents types de caillés. In : Le Fromage, A. Eck. Ed., Lavoisier, Paris, 219-248.

Pette J.W., Lolkema H., 1950a. Yoghurt. I. Symbiose en antibiose in mengcultures van $L b$. bulgaricus en St. thermophilus. Neth. Milk Dairy J., 4, 199-208.

Pette J.W., Lolkema H., 1950b. Yoghurt. II. Growth stimulating factor for Streptococcus thermophilus. Neth. Milk Dairy J., 4, 209-224.

Poznanski S., Surazynski A., O’Obyrn T., 1968. Activité de fermentation et de protéolyse de certaines souches de bactéries lactiques en présence d'acides gras. Lait, 48, 261-274.

Pulusani J.R., Rao D.R., SunKi G.R., 1979. Antimicrobial activity of lactic cultures : partial purification and characterization of antimicrobial compounds produced by Streptococcus thermophilus. J. Food Sci., 44, 575-578.

Radke-Mitchell L., Sandine W.E., 1984. Associative growth and differential enumeration of Streptococcus thermophilus and Lactobacillus bulgaricus, J. Food Prot., 47, 245-248.

RErrer B., 1978. Bacterial inhibitors in milk and other biological secretions, with special reference to the complement/antibody, transferrin/lactoferrin, and lactoperoxidase/thiocyanate/hydrogen peroxide systems. In : Streptococci, Skinner F.A., et Quesnel L.B., ed., Academic Press Inc., Londres, 31-60.

Retrer B., Oram J.D., 1962. Nutritional studies on cheese starters. I. Vitamin and amino acid requirements of single strain starters $J$. Dairy Res., 29, 63-77.

Retter B., Härnvuld G., 1984. Lactoperoxidase antibacterial system : natural occurrence, biological functions, and practical applications. J. Food Prot., 47, 724-732.

Shahani K.M., VAKIL J.R., Kilara A., 1976. Natural antibiotic of Lactobacillus acidophilus and bulgaricus. Cult. Dairy Prod. J., 11, 14-17.

ShAHANI K.M., VAKIL J.R., Killara A., 1977. Natural antibiotic of Lactobacillus acidophilus and Lactobacillus bulgaricus. II. Isolation of acidophilin from Lactobacillus acidophilus. Cult. Dairy Prod. J., 12, 8-11.

Shankar P.A., Davies F.L., 1977a. Amino acid and peptide utilization by Streptococcus thermophilus in relation to yoghurt manufacture. J. Appl. Bacteriol., 43, viii.

Shankar P.A., Davies F.L., 1977b. Associative growth in yoghurt starters ; initial observations on stimulatory factors. J. Soc. Dairy Technol., 30, 31-32.

Shankar P.A., Davies F.L., 1978. Interrelationships of Streptococcus thermophilus and Lactobacillus bulgaricus in yoghurt starters. $X X^{\varepsilon}$ Int. Dairy Congr., Paris, E, 514-515.

SHEKaR S., Bhat G.S., 1983. Influence of dissolved oxygen on acid production in buffalo milk by lactic cultures, J. Food Prot., 46, 321-324.

Smaczny T., Kramer J., 1984. Saeurungsstoerungen in der Joghurt-, Bioghurt- und Biogarde produktion, bedingt durch bakteriocine und bakteriophagen von Streptococcus thermophilus. Dtsch. Molk. Ztg., 105, 460-461, 464.

Somkuti G.A., Steinberg D.H., 1979. Adaptability of Streptococcus thermophilus to lactose, glucose and galactose. J. Food Prot., 42, 885-887.

SPECKMAN R.A., Collins E.B., 1968. Diacetyl biosynthesis in Streptococcus diacetylactis and Leuconostoc citrovorum. J. Bacteriol., 95, 174-180.

Spillman H., Puhan Z., Banhegri M., 1978. Antimikrobielle Aktivität thermophiler Lactobaziller. Milchwissenschaft, 33, 148-153.

Stadhouders J., Leenders G.J.M., 1984. Spontaneously developed mixed-strain cheese starters. Their behaviour towards phages and their use in the dutch cheese industry. Neth. Milk Dairy J., $38,157-181$.

Thomas T.D., Crow V.L., 1983. Lactose and sucrose utilization by Streptococcus thermophilus. FEMS Microbiol. Lett., 17, 13-17.

Thomas T.D., Mrlls O.E., 1981. Proteolytic enzymes of starter bacteria. Neth. Milk Dairy J., 35 , 255-273.

Tinson W., Broome M.C., Hrllier A.J., Jago G.R., 1982. Metabolism of Streptococcus thermophilus. II. Production of $\mathrm{CO}_{2}$ and $\mathrm{NH}_{3}$ from urea. Aust. J. Dairy Technol., 37, 14-16.

Turner K.W., Morris H.A., Martley F.G., 1983. Swiss-type cheese. II. The role of thermophilic lactobacilli in sugar fermentation. N.Z.J. Dairy Sci. Technol., 18, 117-123. 
UPRETI G.C., HINSDILL R.D., 1973. Isolation and characterization of a bacteriocin from a homofermentative lactobacillus. Antimicrob. Agents Chemother., 4, 487-494.

UpRETI G.C., Hinsdill R.D., 1975. Production and mode of action of lactocin 27 : bacteriocin from a homofermentative lactobacillus. Antimicrob. Agents Chemother., 7, 139-145.

Veringa H.A., Galesloot T.E., Davelaar H., 1968. Symbiosis in yoghurt. II. Isolation and identification of a growth factor for Lactobacillus bulgaricus produced by Streptococcus thermophilus. Neth. Milk Dairy J., 22, 114-120.

Wright C.T., Klaenhammer T.R., 1984. Phosphated milk adversely affects growth, cellular morphology and fermentative ability of Lactobacillus bulgaricus. J. Dairy Sci., 67, 44-51.

Wright R.C., Tramer J., 1958. Factors influencing the activity of cheese starters. The role of milk peroxydase. J. Dairy Res., 25, 104-118. 